\title{
USE OF AFLPS TO DISTINGUISH LANDRACES OF PEJIBAYE (Bactris gasipaes) IN BRAZILIAN AMAZONIA
}

\author{
Charles R. Clement ${ }^{1,5 *}$; Nelcimar Reis Sousa ${ }^{2}$; Doriane Picanço Rodrigues ${ }^{3}$; Spártaco Astolfi- \\ Filho $^{3}$; Yolanda Núñez Moreno; Vicente Torres Pascual4; Francisco Javier Gallego Rodríguez ${ }^{4}$ \\ ${ }_{2}^{1}$ CPCA/INPA, C. P. 478 - CEP: 69011-970 - Manaus, AM. \\ ${ }^{2}$ Embrapa Amazônia Ocidental, C.P. 319 - CEP: 69011-970 - Manaus, AM. \\ ${ }^{3}$ Instituto de Ciências Biológicas - Universidade Federal do Amazonas, Av. Gal. Rodrigo Otávio Jordão Ramos, \\ 3000 - CEP: 69077-000 - Manaus, AM. \\ ${ }^{4}$ Instituto Nacional de Investigación y Tecnología Agraria y Alimentaria (INIA), Unidad de Marcadores Moleculares, \\ Dpto. Mejora Genética y Biotecnología, Autovia A-6 Km 7,5, 28040 Madrid, España \\ ${ }^{5} \mathrm{CNPq}$ Fellow. \\ ${ }^{*}$ Corresponding author <cclement@internext.com.br>
}

ABSTRACT: Although the first inhabitants of western Amazonia domesticated pejibaye (Bactris gasipaes Kunth, Palmae) or peach palm for its fruits, today it is widely planted for its heart-of-palm. Like other domesticates, pejibaye presents a complex hierarchy of landraces developed before the conquest of the Americas. The existence of three landraces (Pará, Solimões, Putumayo) was proposed along the Amazonas and Solimões Rivers, Brazil, based on morphological characteristics. There are some questions remaining about the intermediate landrace being an artifact of the morphometric analysis. AFLPs were used to evaluate the relationships among samples of these putative landraces. DNA was extracted from 99 plants representing 13 populations maintained in the Pejibaye Germplasm Bank, Manaus, AM; six primer combinations generated 245 markers via PCR, which were scored in an ABI Prism 310 sequencer and analyzed with GeneScan Software; Jaccard similarities were estimated and a dendrogram was generated with UPGMA. Two groups of plants were observed in the dendrogram instead of three, and were similar at 0.795 . Each group contained two subgroups, similar at 0.815 . One group $(n=41)$ contained $73 \%$ Pará landrace plants, with one subgroup $(n=22)$ containing $91 \%$ Pará, and the other $(n=19)$ containing $53 \%$ Pará. The other group $(n=58)$ contained $53 \%$ Solimões and $40 \%$ Putumayo landrace plants, with one subgroup $(n=21)$ containing $52 \%$ Solimões and $43 \%$ Putumayo, and the other $(n=35)$ containing $57 \%$ Solimões and $37 \%$ Putumayo. The first group confirmed the Pará landrace. The second group suggested that the Solimões landrace does not exist, but that the Putumayo landrace extends along the Solimões River to Central Amazonia.

Key words: molecular markers, population differentiation, genetic resources, genetic analysis

\section{USO DE AFLPS PARA DISCRIMINAR RAÇAS PRIMITIVAS DE PUPUNHA (Bactris gasipaes) NA AMAZÔNIA BRASILEIRA}

RESUMO: Os primeiros povos da Amazônia ocidental domesticaram a pupunha (Bactris gasipaes Kunth, Palmae) por seu fruto, embora hoje seja muito plantada por seu palmito. Como outros cultivos domesticados, a pupunha apresenta uma hierarquia complexa de raças primitivas criadas antes da conquista das Américas. A existência de três raças (Pará, Solimões, Putumayo) foi proposta ao longo dos rios Amazonas e Solimões, Brasil, com base em características morfológicas. Algumas dúvidas existem sobre a raça intermediária, pois podia ser um artefato da análise morfométrica. AFLPs foram usados para avaliar as relações entre amostras destas raças hipotéticas. DNA foi extraido de 99 plantas representando 13 populações mantidas no Banco de Germoplasma de Pupunha, Manaus, AM; seis combinações de 'primers' geraram 245 marcadores via PCR, que foram codificados num sequenciador ABI Prism 310 e analisados com o programa GeneScan; similaridades de Jaccard foram estimadas e um dendrograma foi criado com UPGMA. Dois grupos de plantas foram observados no dendrograma, em lugar de três, com similaridade de 0,795. Cada grupo continha dois subgrupos, similares a 0,815 . Um grupo $(n=41)$ continha $73 \%$ de plantas da raça Pará, com um subgrupo $(n=22)$ contendo $91 \%$ Pará e o outro $(n=19)$ contendo $53 \%$ Pará. O outro grupo $(n=58)$ continha $53 \%$ de plantas da raça Solimões e $40 \%$ da Putumayo, com um subgrupo $(n=21)$ contendo $52 \%$ Solimões e $43 \%$ Putumayo, e o outro ( $n=35$ ) contendo $57 \%$ Solimões e $37 \%$ Putumayo. O primeiro grupo confirmou a raça Pará, mas o segundo grupo sugeriu que a raça Solimões não existe; em lugar desta raça, a raça Putumayo se extende ao longo do rio Solimões até a Amazônia Central.

Palavras-chave: diferenciação populacional, recursos genéticos, marcadores moleculares, análise genética

\section{INTRODUCTION}

Pejibaye (Bactris gasipaes Kunth, Palmae) is widely distributed in the lowland humid Neotropics (Mora Urpí et al., 1997), and its cultivated populations contain ample genetic diversity due to their different stages of domestication in different environments, as well as to pejibaye's mainly allogamous reproductive system. There is a complex hierarchy of landraces, that has been partially characterized morphologically and 
mapped (Mora Urpí \& Clement, 1988). These landraces were created by the first inhabitants of Amazonia over a period of thousands of years, starting from different genetic bases, resulting in each landrace being morphologically and chemically different, and having different yield potential (Mora Urpí et al., 1997). Each landrace is also expected to be genetically different.

Morphometric characterization, using a descriptor list designed for both in situ and ex situ use (Clement, 1986), allowed the classification of several Amazonian landraces of pejibaye (Mora Urpí \& Clement, 1988). The landraces were grouped by fruit size into 'microcarpa', 'mesocarpa' and 'macrocarpa,' because fruit size is thought to reflect their degree of domestication. The Pará landrace (microcarpa) occurs along the Amazonas River, Brazil, and has small, oily and fibrous fruits, with numerous fruits/bunch (Clement, 1987). The Solimões landrace (mesocarpa) occurs along the lower and middle Solimões River, Brazil, has intermediate size fruits and bunches, and is one of the best for direct consumption because of its texture and moderate levels of carotene and oil, which appear to contribute to its agreeable flavor (ibid.). The Putumayo landrace (macrocarpa) occurs along the upper Solimões River, Brasil, and adjacent areas of Colombia and Peru, has large, starchy fruits and few fruits/bunch (ibid.), and is starting to supply raw material to the new agribusiness producing flour for human consumption, both in western Amazonia and in Acre state.

Based on this morphometric characterization, Clement (1986) evaluated the phenetic relationships among eight Amazonian landraces with discriminant analysis. Only the three landraces along the Solimões and Amazonas Rivers were not well discriminated, as demonstrated by the overlap of the standard error volumes around their centroids. This overlap suggested that there was significant introgression between the landraces (a logical assumption due to their linear distribution along these rivers) or that the Solimões landrace was an artifact of the morphometric analysis (since the discriminant analysis was based on the visual impressions of a group of researchers (Mora Urpí \& Clement, 1988), rather than being based on an exploratory analysis, e.g., principal components). These doubts about the Solimões landrace can probably be resolved by molecular analysis.

Currently, molecular markers are important complementary tools for germplasm characterization (Ferreira \& Grattapaglia, 1996) and, consequently, for identification of populations and landraces. Due to lack of environmental effects, molecular markers are more reliable across environments than morphological traits. The AFLP technique is based on PCR amplification of restriction fragments from digested total DNA. PCR primers partially complementary to the adapters and the restriction site are used to create multiple marker bands (Vos et al., 1995). AFLP markers have been found to be suitable for studies on genetic diversity (Arens et al., 1998; Rahman et al., 1998).
Sousa et al. (2001) used RAPDs to evaluate the status of the Solimões landrace. They found that it is probably an extension of the Putumayo landrace, rather than a distinct landrace, but their results suggested the necessity of more sophisticated analysis, especially due to the lack of grouping of plants of the same progeny and distances more typical of species than of populations. The objective of this study was to evaluate the three landrace hypothesis (Pará, Solimões and Putumayo) along the Solimões and Amazonas Rivers using AFLPs to characterize the pejibayes present there and also to expand the preliminary RAPD analysis of Sousa et al. (2001).

\section{MATERIAL AND METHODS}

In Brazilian Amazonia, the National Research Institute for Amazonia (INPA) maintains the Pejibaye Active Germplasm Bank (BR 174, km 38, Manaus, AM, Brazil; $2^{\circ} 30^{\prime} \mathrm{S} ; 60^{\circ} 15^{\prime} \mathrm{W}$ ), in collaboration with Embrapa Recursos Genéticos and Embrapa Amazônia Ocidental. The bank contains 450 accessions collected from cultivated and wild populations of pejibaye and 5 from related species. This study used 34 plants from the Pará, 32 from the Solimões and 33 from the Putumayo landraces, from a total of 13 populations (Figure 1). Eighty one of these plants were the same as those used by Sousa et al. (2001), allowing validation of their study. The plants were selected to represent the Brazilian distribution of the Putumayo landrace, the majority of the distribution of the Solimões landrace (the eastern part is poorly represented in the bank), and the western and eastern parts of the Pará landrace (the central part is poorly represented in the bank).

DNA was extracted with the DNAsy Plant Minikit (Quiagen) from $100 \mathrm{mg}$ of apical meristem of a lateral shoot, as explained by Clement et al. (1997) for extraction of enzymes, yielding an average ( \pm standard error) of 14.4 $\pm 6.0 \mu \mathrm{g}$ of DNA (minimum 3.2; maximum $28 \mu \mathrm{g}$ ). The DNA was analysed at Madrid's National Agricultural Research Institute (INIA).

AFLP markers were developed following the protocol supplied by Perkin Elmer (1995), based on Vos et al. (1995). DNA digestion was carried out using the restriction enzymes EcoRI and Msel. Forty-two combinations of primers (Table 1) were tested for number of fragments, ample fragment size range and sufficient fluorescent emission, and six pairs were chosen and grouped in two sets. Set $A$ included the following sequences: $A C A / C A C, A A G / C T G$ and $A A C / C T G$. Set $B$ comprised the sequences $A C T / C A G, A A G / C A G$ and AGC/CAG.

Aliquots $(2 \mu \mathrm{L})$ of $\mathrm{PCR}$ products were mixed with $12 \mu \mathrm{L}$ of formamide and $0.5 \mu \mathrm{L}$ of a red DNA size standard (GENESCAN-500 ROX). Samples were denatured at $94^{\circ} \mathrm{C}$ for 3 min prior to separation by capillary electrophoresis at $15 \mathrm{kV}$ for $25 \mathrm{~min}$ in an $\mathrm{ABI}$ Prism 310 DNA Sequencer 
Table1 - Number of AFLP fragments of pejibaye DNA detected with 42 primer combinations.

\begin{tabular}{lccc}
\hline Primer combination & No. of fragments & Primer combination & No. of fragments \\
\hline E-CAA/M-ACA & 58 & E-CAT/M-ACT & 68 \\
E-CAA/M-AAG & 103 & E-CAT/M-AGG & 0 \\
E-CAA/M-AAC & 102 & E-CAT/M-AGC & 82 \\
E-CAA/M-ACT & 136 & E-CTA/M-ACA & 27 \\
E-CAA/M-AGG & 0 & E-CTA/M-AAG & 29 \\
E-CAA/M-AGC & 97 & E-CTA/M-AAC & 40 \\
E-CAC/M-ACA & $62^{*}$ & E-CTA/M-ACT & 51 \\
E-CAC/M-AAG & 94 & E-CTA/M-AGG & 0 \\
E-CAC/M-AAC & 78 & E-CTA/M-AGC & 81 \\
E-CAC/M-ACT & 83 & E-CTC/M-ACA & 77 \\
E-CAC/M-AGG & 0 & E-CTC/M-AAG & 86 \\
E-CAC/M-AGC & E-CTC/M-AAC & 62 \\
E-CAG/M-ACA & 60 & E-CTC/M-ACT & 70 \\
E-CAG/M-AAG & 63 & E-CTC/M-AGG & 0 \\
E-CAG/M-AAC & $59^{*}$ & E-CTC/M-AGC & 81 \\
E-CAG/M-ACT & 63 & E-CTG/M-ACA & 0 \\
E-CAG/M-AGG & $47^{*}$ & E-CTG/M-AAG & $71^{*}$ \\
E-CAG/M-AGC & 0 & E-CTG/M-AAC & $53^{*}$ \\
E-CAT/M-ACA & $48^{*}$ & E-CTG/M-ACT & 65 \\
E-CAT/M-AAG & 48 & E-CTG/M-AGG & 0 \\
E-CAT/M-AAC & 102 & E-CTG/M-AGC & 48 \\
\hline
\end{tabular}

${ }^{* *}$ selected primer combinations.

$\mathrm{E}=E c o \mathrm{RI}$ and $\mathrm{M}=M$ sel in the primer descriptions.

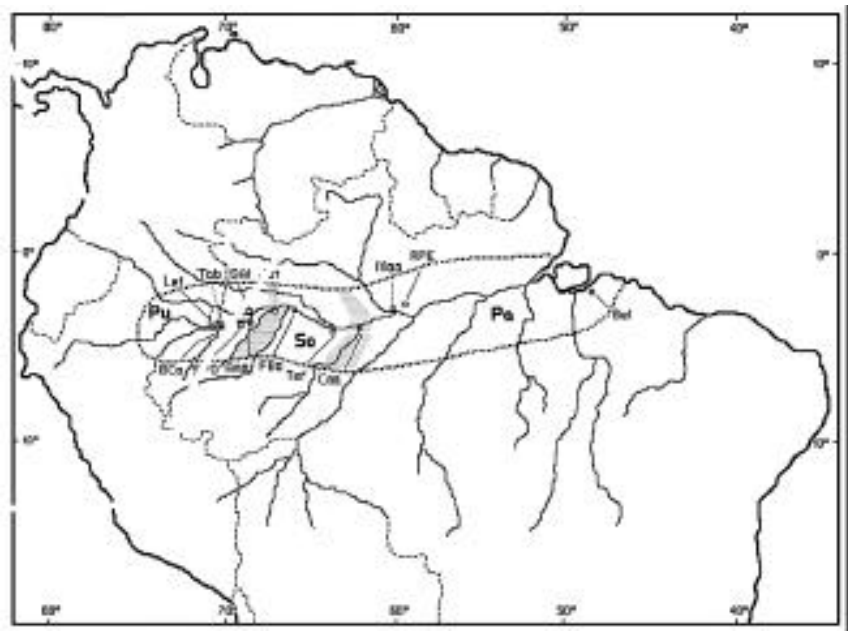

Figure 1 - Geographic distribution of the Pará, Solimões and Putumayo landraces of pejibaye (Bactris gasipaes) in Brasilian Amazonia. The sampled populations were: Pará - Belém (Bel: 5 accessions; 13 plants), Manaus (Mao: 4 ac; 8 pl), Rio Preto de Eva (RPE: 6 ac; $13 \mathrm{pl}$ ); Solimões - Coarí (Coa: 1 ac; 1 pl), Fonte Boa (FBo: 8 ac; 17 pL), Jutaí (Jut: 2 ac; 5 pl), Tefé (Tef: 4 ac; 9 pl); Putumayo - Amaturã (Ama: 2 ac; 5 pl), Benjamin Constant (BCo: 3 ac; 8 pl), Leticia, Colombia (Let: 2 ac; 4 pl), Santo Antonio do Íçá (SAl: 1 ac; 2 pl), São Paulo de Olivença (SPO: 1 ac; 2 pl), Tabatinga (Tab: $6 \mathrm{ac} ; 12 \mathrm{pl})$. Hatched bands represent areas of probable introgression between landraces.
(PE Biosystems) and analyzed by using Genescan Analysis software 3.1 (PE Biosystems).

The number of fragments generated by each pair of primers was obtained directly from the Genescan Analysis software, using the Local Southern method to size the fragments. On the basis of presence and absence of amplification products, data matrices were built. Genetic distances were estimated using Jaccard's algorithm. This coefficient was used for clustering data with the UPGMA method (Rolf, 1990).

\section{RESULTS AND DISCUSSION}

Eight of the 42 combinations of primers failed to amplify (Table 1). The 34 combinations that amplified yielded 2377 fragments ( 70 bands per primer pair), in the size range of $50 \mathrm{bp}$ to $500 \mathrm{bp}$. Six combinations that generated an intermediate number of fragments, with ample size range and with enough fluorescent emission to be detected were chosen. After discarding the peaks that were difficult to score, a total of 245 fragments for analysis were selected, of which $135(55.10 \%)$ were polymorphic between two or more samples.

The dendrogram contained two large groups that joined at a similarity of 0.795 (Figure 2), rather than three groups expected if the three landrace hypothesis was valid, as also found by Sousa et al. (2001). The smaller group contained 41 plants, of which 30 were from the 
Pará, 10 from the Putumayo and one from the Solimões landraces, and corresponds aproximately to the Pará landrace, since $73 \%$ of the plants are from that landrace. The larger group contained 58 plants, of which 31 were from the Solimões, 23 from the Putumayo and 4 from the Pará landraces, and will henceforth be called the Solimões River group because the Solimões (53\%) and the Putumayo (40\%) were roughly similar in importance.

Each large group was composed of two subgroups and, in the case of the Solimões River group, two outliers, one from the Pará and one from the Putumayo landraces (Figure 2). In both groups, the subgroups were joined at similarities close to 0.815 .

The first subgroup of the Pará landrace contained 22 plants (91\% Pará), of which 13 (of 13 sampled) from Belém (eastern Pará landrace), five from Rio Preto de Eva (western Pará landrace), two from Manaus (western Pará), one from Tabatinga (Putumayo) and one from Coarí (Solimões). This was a very homogeneous subgroup and appeared to represent the Pará landrace well. The second subgroup contained 19 plants (53\% Pará), of which six from Manaus (western Pará landrace), four from Rio Preto da Eva (western Pará), five from Amaturá, two from Tabatinga and two from São Paulo de Olivença (all eastern Putumayo). This sub-group was very heterogenous and only marginally dominated by Pará landrace plants. Mora Urpí \& Clement (1988) proposed that the principal urban centers of Amazonia, such as Manaus, are centers of hybridization, which may help to explain the heterogeneity of the second subgroup, although possible errors (see below) can not be ignored.

The first subgroup of the Solimões River group contained 21 plants (52\% Solimões; $43 \%$ Putumayo), of which seven from Fonte Boa (western Solimões), three from Tefé (central Solimões), one from Jutaí (western Solimões), three from Letícia, three from Benjamin Constant, two from Tabatinga, one from Santo Antônio do Iça (all Putumayo), and one from Rio Preto de Eva (western Pará). The second subgroup contained 35 plants (57\% Solimões; 37\% Putumayo), of which 10 from Fonte Boa, six from Tefé, four from Jutaí (all Solimões), seven from Tabatinga, five from Benjamin Constant, one from Letícia (all Putumayo) and two from Rio Preto de Eva (western Pará). The two subgroups had similar mixtures of Solimões and Putumayo, with no apparent organization within either group, similar to the situation reported by Sousa et al. (2001). This apparently random mixture of the two landraces suggests that the Solimões landrace does not exist at the level of DNA, as visualized with AFLPs, as also reported by Sousa et al. (2001).

However, there were some unexpected results that need clarification, as also presented by Sousa et al. (2001). Plants of the same accession (members of a progeny that originated from the same open-pollinated female plant) rarely clustered together, although they almost always clustered in the correct group: three pairs

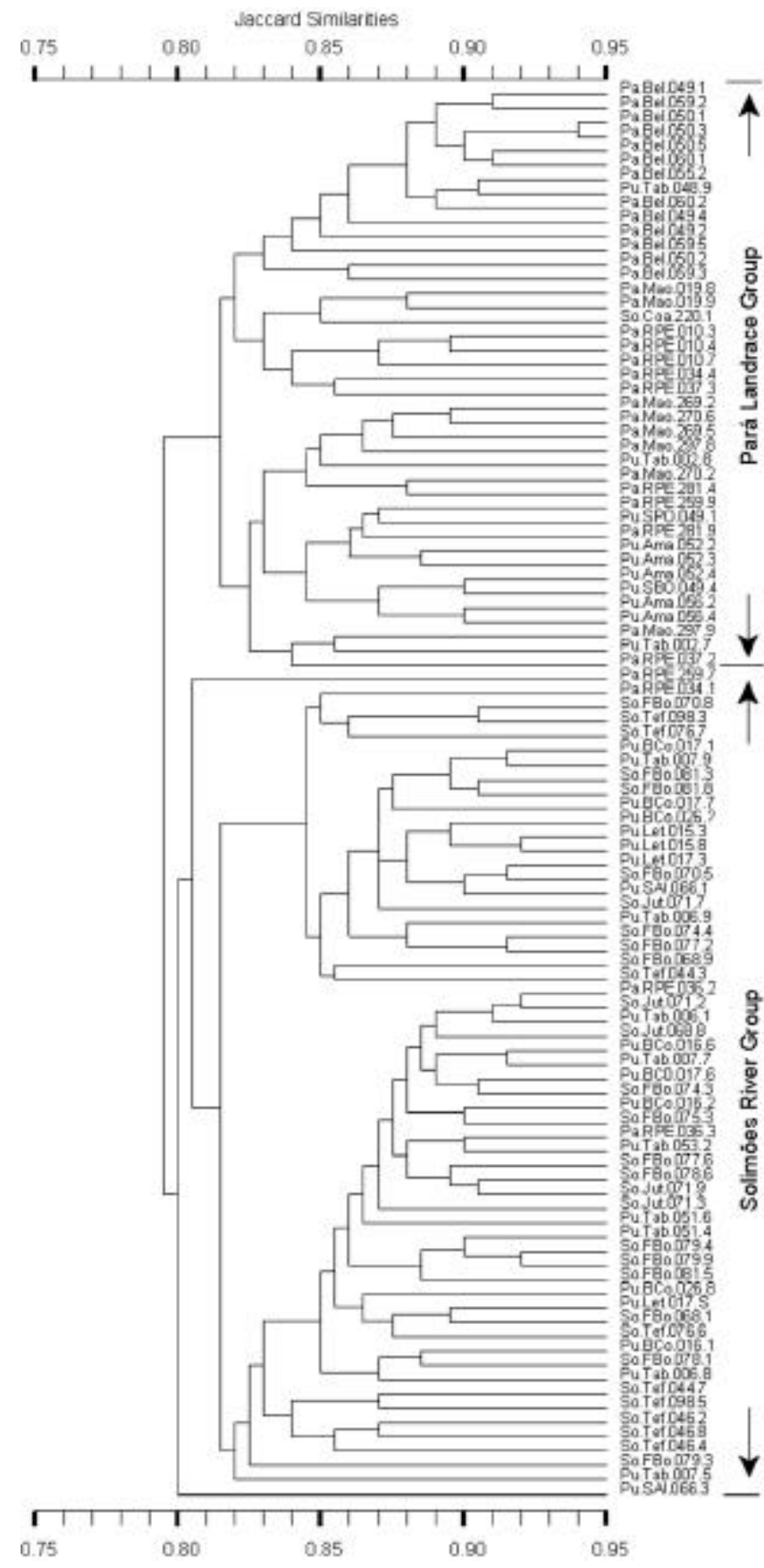

Figure 2 - Dendrogram of the relationships among plants of pejibaye (Bactris gasipaes) based on Jaccard's similarities (245 AFLP markers). Key: rr.ppp.nnn.n, where $r$ are the first letters of the landrace name, ppp are the abbreviations of the populations listed in Figure 1, and nnn.n are accession and plant numbers in the Pejibaye Germplasm Bank, INPA, Manaus, AM.

of Pará plants and one pair of Putumayo in the Pará group; three pairs of Solimões plants and one pair of Putumayo in the Solimões River group. Although the lack of expected clustering was also observed in the American oil palm (Elaeis oleifera Cortes), it was an exception rather than the norm in that species (Edson Barcelos, Embrapa, pers. com.). Also, in each group there were intrusive plants: in the Solimões River group there were 
four Pará plants, while in the Pará group there were 10 Putumayo plants and one Solimões plant. Both of these unexpected results suggest that there may be errors of identification in the Pejibaye germplasm bank, or sampling and handling errors occurred during collection and laboratory work, or they represent plants introduced from the original landrace into the current. These plants all need to be reanalyzed to clarify their anomalous position in this study.

Sousa et al. (2001) found that the similarities among plants and groups using RAPDs were less than expected. Using AFLPs, the similarities were much closer to expectation, ranging from 0.96 in one Pará progeny (versus 0.85 for the same progeny in Sousa et al. (2001) to 0.82 for the extreme outlier of the Solimões River group (versus 0.54 for its extreme outlier). The major groups joined at nearly 0.80 with AFLPs, while they joined at 0.53 with RAPDs. These differences confirm the greater reliability of AFLPS (Ferreira \& Grattapaglia, 1996).

\section{CONCLUSIONS}

Using AFLP markers, only two groups were found instead of three, suggesting that the original hypothesis is not valid. The composition and mixture of the Solimões River group suggests that the Putumayo landrace extends along the Solimões River at least to Tefé and possibly to Coarí, instead of being restricted to the upper Solimões River, as originally proposed by Mora Urpí \& Clement (1988). Nonetheless, this genetic analysis does not clarify the entire question; for example, the location of the eastern limit of the Putumayo and the western limit of the Pará landraces remains uncertain. A more complete sample of these landraces, with better representation of unclarified areas, will be necessary, and may be enriched with morphometric data as well.

\section{ACKNOWLEDGMENTS}

This research was supported by grants of the Pilot Program to Protect the Tropical Forests of Brazil
(PPG-7) - Projetos FINEP $n^{\circ}$ 0930/95 (Embrapa Amazônia Ocidental) and 0869/95 (INPA), and with institutional resources of the Instituto Nacional de Investigación y Tecnología Agraria y Alimentaria (INIA), Unidad de Marcadores Moleculares, Depto. Mejora Genética y Biotecnología, Madrid, España.

\section{REFERENCES}

ARENS, P.; COOPS, H.; JANSEN, J.; VOSMAN, B. Molecular genetic analysis of black poplar (Populus nigra L.) along Dutch rivers. Molecular Ecology, v.7, p.11-18, 1998

CLEMENT, C.R. Descriptores mínimos para el pejibaye (Bactris gasipaes H.B.K.) y sus implicaciones filogenéticas. San José, Costa Rica, 1986. 216p. Thesis (M.Sc.) - Escuela de Biologia, Universidad de Costa Rica.

CLEMENT, C.R. A pupunha, uma árvore domesticada. Ciência Hoje, v.5, p.42-49, 1987.

CLEMENT, C.R.; ARADHYA, M.K.; MANSHARDT, R.M. Allozyme variation in spineless pejibaye (Bactris gasipaes Palmae). Economic Botany, v.51, p.149-157, 1997.

FERREIRA, M.E.; GRATTAPAGLIA, D. Introdução ao uso de marcadores moleculares em análise genética. Brasília: EMBRAPA, CENARGEN, 1996. 220p.

MORA URPÍ, J.; CLEMENT, C.R. Races and populations of peach palm found in the Amazon basin. In: CLEMENT, C.R.; CORADIN, L. (Ed.) Final report (revised): peach palm (Bactris gasipaes H.B.K.) germplasm bank (U.S A.I.D. project report). Manaus: INPA; CENARGEN, 1988. p.78-94.

MORA URPÍ, J.; WEBER, J.C.; CLEMENT, C.R. Peach palm. Bactris gasipaes Kunth. Promoting the conservation and use of underutilized and neglected crops. 20. Gatersleben: Institute of Plant Genetics and Crop Plant Research - IPK; Rome: International Plant Genetic Resources Institute - IPGRI, 1997. 83p.

PERKIN ELMER. AFLP plant mapping kit protocol (P/N 402083). Foster City: Perkin Elmer, 1995.

RAHMAN, M.S.M.; SHIMADA, T; YAMAMOTO, T; YONEMOTO, J.Y YOSHIDA, M. Genetical diversity of cherimoya cultivars revealed by amplified fragment length polymorphism (AFLP) analysis. Breeding Science, v.48, p.5-10, 1998.

ROLF, F.J. NTSYS-pc - Numerical taxonomy and multivariate analysis system, ver. 1.6. Setauket: Exeter Software, 1990.

SOUSA, N.R.; RODRIGUES, D.P.; CLEMENT, C.R.; NAGAO, E.O.; ASTOLFIFILHO, S. Discriminação de raças primitivas de pupunha (Bactris gasipaes) na Amazônia brasileira por meio de marcadores moleculares (RAPDs). Acta Amazonica, v.31, p.539-545, 2001.

VOS, P.; HOGERS, R.; BLEEKER, M.; REIJANS, M.; LEE, T. VAN DE; HORNES, M.; FRIJTERS, A.; PLOT, J.; PELEMAN, J.; KUIPER, M.; ZABEAU, M. AFLP: a new technique for DNA fingerprinting. Nucleic Acids Research, v.23, p.4407-4414, 1995.

Received June 29, 2001 